\title{
Puberty stages of primary school students
}

\author{
Aditya Suryansyah \\ From 7th APPES Biennial Scientific Meeting \\ Nusa Dua, Bali. 14-17 November 2012
}

\section{Background}

Puberty is the transition from child to adult. Signs of puberty begin 8-13 years of age in girls and 9-14 years in boys. Puberty begins with breast budding in girls and enlargement of the testes in boys.

\section{Purpose}

Knowing the early signs of Puberty in primary school students in South Tangerang, Indonesia.

\section{Method}

This is a descriptive cross sectional study of 4th-6th grade to students in two primary schools in South Jakarta, in January 2011.

\section{Results}

There are 471 samples met the inclusion criteria, 215 boys and 256 girls. In girls, signs of puberty at age of $9-<10$ years are $48.2 \%$, while in age $12-<13$ all had puberty. In boys, signs of puberty at age of $9-<10$ years are $1.7 \%$, while in age $12-<13$ years are $66.7 \%$. Pubic hair sign in girls at the age of $9-<10$ years $(4.4 \%)$, in boys aged 11 $<12$ years (29\%). Occurred menarche at age $10-<11$ years (5.7\%).

\section{Conclusion}

Signs of puberty in two primary school students in South Tangerang has occurred in the age of $9-<10$ years, both women and men. At the age of $12-<13$ entered puberty had all girls, while boys are not in all (66.7\%). In women, the pubic hair appear earlier than men. Menarche occurred from children aged $10-<11$ years.

Published: 3 October 2013

Endocrinology Unit, Harapan Kita Women and Children Hospital, Jakarta, Indonesia

(C) 2013 Suryansyah; licensee BioMed Central Ltd. This is an Open Access article distributed under the terms of the Creative Commons Attribution License (http://creativecommons.org/licenses/by/2.0), which permits unrestricted use, distribution, and reproduction in any medium, provided the original work is properly cited.
doi:10.1186/1687-9856-2013-S1-P82

Cite this article as: Suryansyah: Puberty stages of primary school

students. International Journal of Pediatric Endocrinology 2013

2013(Suppl 1):P82.
Submit your next manuscript to BioMed Central and take full advantage of:

- Convenient online submission

- Thorough peer review

- No space constraints or color figure charges

- Immediate publication on acceptance

- Inclusion in PubMed, CAS, Scopus and Google Scholar

- Research which is freely available for redistribution Submit your manuscript at
www.biomedcentral.com/submit

C Biomed Central 